Lerche J, Seppanen. O, Pedersen. KB, Neve. H, Wandahl. S, Gross, A. (2019). "Why would location-based scheduling be applicable for offshore wind turbine construction?" In: Proc. $27^{\text {th }}$ Annual Conference of the International. Group for Lean Construction (IGLC), Pasquire C. and Hamzeh F.R. (ed.), Dublin, Ireland, pp. 1283-1294. DOI: https://doi.org/10.24929/2019/0121 Available at: <www.iglc.net>.

\title{
WHY WOULD LOCATION-BASED SCHEDULING BE APPLICABLE FOR OFFSHORE WIND TURBINE CONSTRUCTION?
}

\author{
Jon Lerche ${ }^{1}$, Olli Seppänen ${ }^{2}$, Kristian Birch Pedersen ${ }^{3}$, Hasse Neve ${ }^{4}$, Søren \\ Wandahl $^{5}$, Allan Gross 6
}

\begin{abstract}
The focus in this research was the conversion of a traditional activity-based construction schedule to a location-based schedule. The case investigated was an offshore wind turbine project in the British sector of the North Sea. This exploratory case study used a deductive approach studying the literature. The initial step was a review of the location-based scheduling literature. The applicability of the theory could be tested through understanding the patterns from existing location-based scheduling literature. These patterns were the adapted from the construction context to the offshore wind construction context. With the knowledge of how and why from a theoretical perspective, the authors analyzed the existing construction schedule which was based on the critical path methodology. The results from this analysis provided knowledge about how location-based scheduling is applicable from an industrial perspective. This research contributes knowledge by testing the theory of location-based scheduling in the context of offshore wind turbine construction industry.
\end{abstract}

\section{KEYWORDS}

Construction, Flowline, LBMS, Offshore wind, Work-sequencing

1 PhD Student, Department of Business Development at Aarhus University, Denmark, +4560133595, jon.lerche@btech.au.dk

2 Professor of Practice, Aalto University School of Engineering, Department of Civil Engineering, Finland, olli.seppanen@aalto.fi

3 PhD, Department of Construction Management at Aalborg University, Denmark, +4553555919, kbp@exigo.dk

4 PhD Student, Department of Engineering at Aarhus University, Denmark, +4528791838, hn@eng.au.dk

5 Professor, Department of Engineering at Aarhus University, Denmark, +4541893216, swa@eng.au.dk

6 Professor, Department of Business Development at Aarhus University, Denmark, +4561150219, agr@btech.au.dk 


\section{INTRODUCTION}

Offshore wind turbine construction divides their projects into distinct phases, namely production, pre-assembly, installation, commissioning (Barlow et al. 2015; Vis and Ursavas 2016). After the construction project the wind farm is handed over to operations (Petersen et al. 2016). This research focuses on the construction activities which start with the pre-assembly at the harbor as described by Barlow et al. (2014), and continues with the installation phase initiated when the jack up vessels arrives at the quay side ready to bring the main components offshore (Barlow et al. 2014; Irawan et al. 2017). Final construction phase is commissioning, where final assembly and testing is conducted prior to operations. The commissioning activities are perceived similar to operations activities, here Petersen et al. (2016) recognized lean as a method for improvements of the maintenance activities. The focus of this research is on scheduling of the construction phases, by means of analyzing an existing activity-based construction schedule.

In previous literature, a few alternative planning and scheduling methodologies have been introduced for offshore wind construction. Alla et al. (2013) illustrated how linear programming with fixed scenarios could be applied for planning the construction of an offshore wind farm. Barlow et al. (2014) focused their perspective at installation of the turbines and how simulation of the installation vessel operations could impact the choice of vessels for strategy purposes. However, these presented examples do not defy the fact that critical path methodology is dominant for planning purposes in multiple industries (Galloway 2006). This is also the case in offshore wind turbine construction projects. For example, Hofmann (2011) presented an overview of multiple CPM based planning methods.

In the field of lean construction, the understanding of construction as a production system was developed through the theory transformation-flow-value by Koskela (2000). The Last Planner® System of Production Control (Ballard 2000) was introduced to plan and control the complexity in construction projects through collaboration and commitments among trades. Kenley (2005) described how construction has been perceived as chaotic by some and how location based management system (LBMS) could reduce its complexity. However, these methods have not been used in offshore wind construction context.

Therefore, this research was motivated by the potential of optimizing the construction planning by adapting the lean construction planning method Last Planner® System of Production Control (Ballard 2000) and location-based management system (LBMS) as introduced by Kenley \& Seppänen (2010). It was chosen to proceed with the LBMS methodology, as a conversion of the existing activity-based schedule would be possible without direct interaction with the project team as described by Olivieri et al. (2018). As LPS is a social process between actors in the system (Ballard 2000), a research attempt to convert the existing schedule to the Last Planner® methodology cannot easily be done without participation of the teams (Ballard 2000). Olivieri et al. (2018) illustrated how LBMS could improve flow and resource usage by converting CPM schedules to LBMS schedules. The scope of the research is thus developing the understanding of the location- 
based scheduling methodology and evaluating if it could be applicable in the offshore wind construction industry.

The first part of the paper describes the contribution to the knowledge of location-based scheduling by a literature review. Then the context of offshore wind turbine construction and lean construction is introduced. The following section will develop the understanding of the exploratory case study with explanation of the theoretical patterns. The theoretical patterns are then adapted and applied to the existing Critical Path Method construction schedule. This leads to the discussion of implications of adapting location-based schedule in offshore wind industry, followed by the conclusions of the research.

\section{BACKGROUND}

The offshore wind energy industry has through years focused on becoming competitive on the levelized cost of energy ( $\mathrm{LCoE}$ ) in comparison to coal and other energy sources. The project costs are directly linked to the $\mathrm{LCoE}$ and equally affected by the tendering bids for new offshore wind farms. Lacal-Arántegui et al. (2018) explains how the tender bids have declined from 140 EUR/ MWh in 2012 to 49EUR in 2020. This has led engineering innovation through upscaling the power output per unit from $3,6 \mathrm{MW}$ in 2008 to $8 \mathrm{MW}$ in 2015(Rodrigues et al. 2015). Another perspective is the vessel innovations to accommodate these increases in dimensions(Paterson et al. 2018). Other sources has been contributing to the cost reduction through optimized planning and scheduling.

\section{METHOD}

The framework for this exploratory case study is inspired by Yin (2014) and used to test existing theory as described by Chris et al. (2002). A deductive approach was chosen to understand why and how the theory of location-based scheduling would adapt to the phenomenon of offshore wind turbine construction. First the theoretical patterns were identified and then the empirical data was analyzed to find similar patterns. The identified theoretical approach and the results follow an identical sequence, both follows the theoretical sequence for replication purposes and a consistent flow in the case study (Yin 1994). This was also used to increase the internal validity. The external validity was increased through setting up planning workshops with the project organization, including the project planner and technical experts. It was required to have multiple participants with each their perspectives on the planning and schedule as the projects are divided in three distinct phases; pre-assembly, installation, and commissioning (Barlow et al. 2014; Vis and Ursavas 2016). The literature review was conducted by searching the databases; Scopus, Google Scholar, and IGLC conference proceedings. The first search string contained; "LBMS", "location-based scheduling", "line-of-balance", "repetitive scheduling", "offshore" and "construction". LBMS was the consistent keyword with the other keywords in various combinations gave zero results. This indicated a gap in the knowledge of why LBMS would be applicable in offshore context. The literature reviewed illustrated different perspectives as illustrated in table 1, differentiating between construction, manufacturing and offshore wind industries. The first column is source, the second is industry, and then methodologies selected which are CPM, LBMS and LPS. Domain and methodology 
combined illustrates a clear gap in the body of knowledge for the offshore wind domain. The method comparison shows that LBMS has been primarily discussed within construction context.

Table 1: Literature comparison, domain and methods

\begin{tabular}{|c|c|c|c|c|c|c|}
\hline \multirow[b]{2}{*}{ Source } & \multicolumn{3}{|c|}{ Domain } & \multicolumn{3}{|c|}{ Method } \\
\hline & 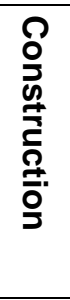 & 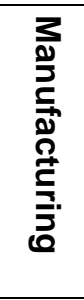 & 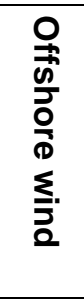 & $\frac{9}{0}$ & 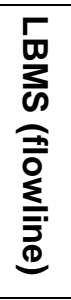 & 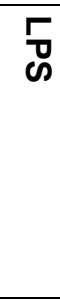 \\
\hline Alla et al. (2013) & & & $\mathrm{x}$ & $\mathrm{x}$ & & \\
\hline Backe and Haugland (2017) & & & $x$ & $x$ & & \\
\hline Ballard, H. G. (2000) & $x$ & & & & & $x$ \\
\hline Barlow et al. (2014) & & & $x$ & $\mathrm{x}$ & & \\
\hline Barlow et al. (2015) & & & $x$ & $x$ & & \\
\hline Devoy McAuliffe et al. (2018) & & & $x$ & $x$ & & \\
\hline Galloway, P. D. (2006) & & $x$ & & $x$ & & \\
\hline Hofmann, M. (2011) & & & $\mathrm{x}$ & $\mathrm{x}$ & & \\
\hline Irawan, C. A., Jones, D., and Ouelhadj, D. (2017) & & & $x$ & $x$ & & \\
\hline Kenley, R. (2005) & $x$ & & & & $\mathrm{x}$ & \\
\hline Kenley, R., and Seppänen, O. (2010) & $x$ & & & & $x$ & \\
\hline Kerzner and Kerzner (2017) & & $x$ & & $\mathrm{x}$ & & \\
\hline Lacal-Arántegui et al. (2018) & & & $x$ & $x$ & & \\
\hline Lucko and Gattei (2016) & $x$ & & & & $x$ & \\
\hline Lucko et al. (2014) & $x$ & & & & $\mathrm{x}$ & \\
\hline Olivieri et al. (2018) & $x$ & & & $x$ & $x$ & \\
\hline Seppänen, O., Ballard, G., and Pesonen, S. (2010). & $x$ & & & & $x$ & $x$ \\
\hline Seppänen, O., Evinger, J., and Mouflard, C. (2014) & $x$ & & & & $x$ & \\
\hline Ursavas (2017) & & & $\mathrm{x}$ & $\mathrm{x}$ & & \\
\hline Valente, Montenegro, Brito, Biotto, and Mota (2014) & $x$ & & & & $x$ & \\
\hline Vis, I. F. A., and Ursavas, E. (2016). & & & $x$ & $x$ & & \\
\hline Vollmann et al. (2004) & & $x$ & & $x$ & & \\
\hline
\end{tabular}

\section{EMPIRICAL DATA}

The empirical data provided is from an existing construction schedule which has been planned for the construction of a wind farm in the British sector of the North Sea. This was initially delivered in an activity-based schedule from the Primavera software. The schedule was then converted to Excel and structured to meet the patterns described. In addition, the 
following information was also used in the transformation to a location-based schedule: site plan of pre-assembly on harbour, the wind farms turbine location overview and the design specifications of the model with power output above 7.0 Mega Watt. The activitybased schedule provided, consists of tasks and durations with their dependencies. The planned resources are kept separately in the original schedule. The case owner provided resources for different workshops, two small workshops with the planner of the existing schedule, first for clarification purposes and to ensure correct interpretation. Second workshop for confirmation of the conversion and potential generalisability. Besides these workshops two independent workshops with construction experts, one foremen and one with an offshore foreman and two commissioning technicians. These with three preassembly workshops were to establish external validy, by confirmation of the converted schedule, locations, tasks and dependencies from a practical and a planning perspective. The scheduling conversion was implemented by using the Schedule Planner module of Vico Office suite by Trimble.

\section{RESULTS}

The following section contains the conversion results from the activity-based schedule to the location-based schedule. Olivieri et al. (2018) thoroughly describe the conversion of CPM registered activities into flowline (LBMS) from 3 cases, with a focus on resource loaded tasks. In this case resources were not considered during investigation of applicability because they add an additional layer on top of LBMS and thus applicability is not directly affected by this. In our case, first the locations were specified. Next, each task was entered with the duration in each location identical to the original schedule.

\section{LOCATION BREAKDOWN STRUCTURE (LBS)}

The LBS was defined as follows; first we reviewed how the structure is set up in construction projects, then we investigated how it would apply in in the offshore wind turbine environment. In construction, the location breakdown structure is hierarchically broken down from the highest structurally independent hierarchy level which contains the lower levels, this can in some situations include logical locations which are non-physical (Kenley and Seppänen 2010). Olivieri et al. (2018) compose tasks by locations which crews complete before moving to next location. Valente et al. (2014) describe how the locations could be divided in equally sizes measured by duration for the trades.

\section{Pre-assembly}

In pre-assembly LBS, the logical areas are divided in hierarchy levels, determining the location flow by completeness and movement of the main components. The levels are described in comparison to Kenley and Seppänen (2010) presentation of construction LBS.

1. Highest level which is structurally independent is the pre-assembly harbor area, in construction this could be the building, stadium etc.

2. Middle levels here are the main components or geographical areas on the harbor, which in construction could be risers, floors or bays. 
3. Lowest level are onshore segregated in; 'laydown area' or 'assembly area', in construction this would be appartments or levels.

\section{Offshore locations}

Offshore the activities move through the product location, similarly to what is seen in construction of high rise buildings. The hierarchy of locations are then being "offshore" which becomes segregated by each individual turbine location and further down into levels or space inside the turbine structures.

1. Highest level here is offshore as it is independent from the pre-assembly level and could be perceived as a second building. If it is a large wind farm it can be further segregated in fields or horizonal position.

2. Middle level are the identified turbine locations in the offshore farm named by numbers or their specific identity tags.

3. Lowest level logically consists of main components as one team at the time can work here, this case did not require this level of detail.

Figure 1 illustrates the location breakdown structure differentiating between onshore preassembly (Vis and Ursavas 2016) and the offshore locations with final assembly (Barlow et al. 2015).

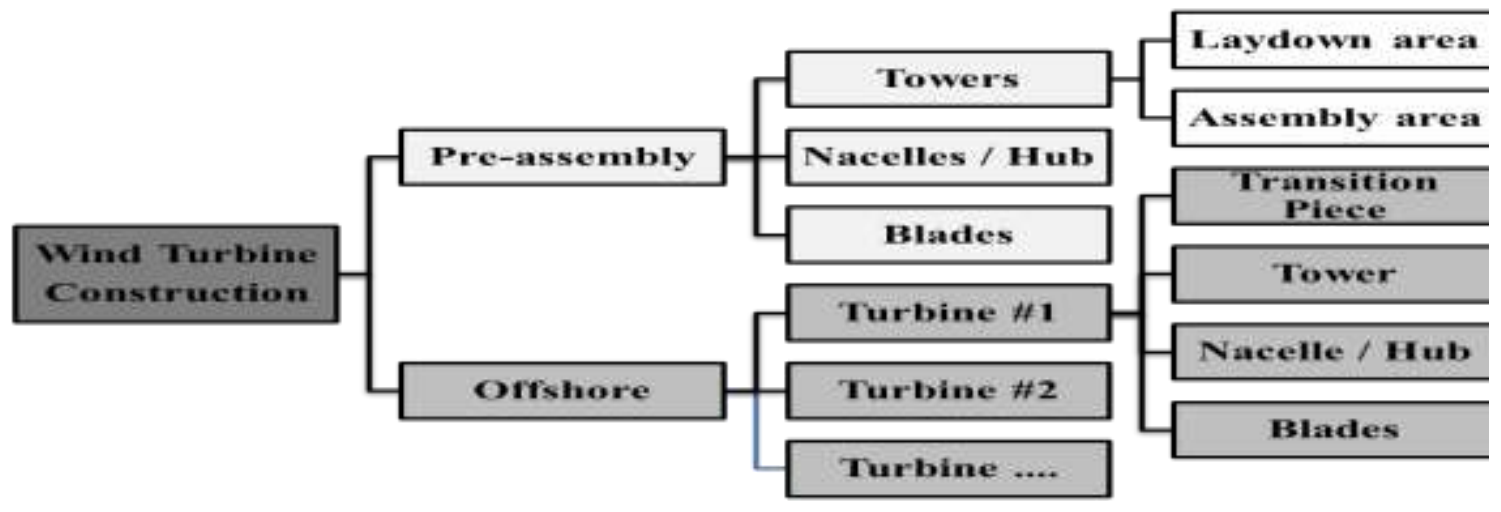

Figure 2: Location breakdown structure offshore wind construction

\section{ACTIVITIES AND DURATIONS}

The case activities in the original CPM schedule were structured by turbine numbering each activity for identification and sequencing purposes, which also made filtering possible in the plan exported to Excel. Here the sequence of a single turbine was investigated. The activities listed under each turbine were repetitive and confirmed the location breakdown structure of Figure 1. The repetitive activities were quantified by hours and could have been changed into flowline tasks, but it was chosen to keep the original activities and durations. The workshops took a starting point in figure 2, this flow view illustrates the high-level shifts between project phases. The figure illustrates how there is a change from pushing to a supermarket onshore, then pulling a batch during installation and finalizing 
by pulling singular turbines in the commissioning phase. From the high-level flow diagram, the workshops focused on the converted schedule ensuring that the sequencing and technical dependencies matched. Having pre-assembly tasks organized until a given set of main components was ready, then in batches these components were transferred to the installation vessel (loadout) (Barlow et al. 2015). After loadout and transfer period, installation was performed in individual locations. When the installation vessel had finalized the installations of a given set it transferred back for a new loadout. This process was repeated until all the turbines had been installed. The commissioning tasks were then planned, including reliability tests and the first service period, leading to the take-over certificate which is final milestone for each turbine in the plan.

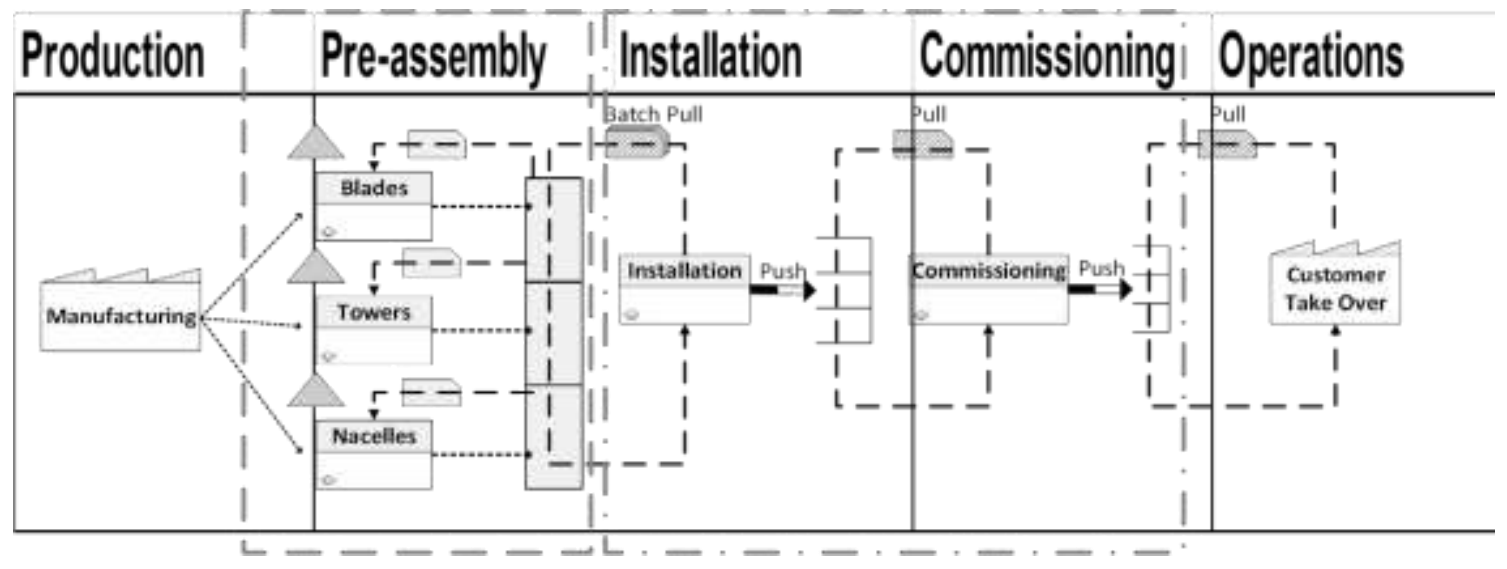

Figure 2: Wind turbine operations product flow chart

\section{DEPENDENCIES}

The CPM activities and their technical dependencies were visible through the consistent sequences, to further generate understanding of the resources per task; the amount of resources and equipment and specific dependencies was clarified by the workshops and process maps. Kenley and Seppänen (2010) specifies the logical layers, which Olivieri et al. (2018) used during their CPM conversion. The known CPM dependencies were not all outlined in the original schedule, which was identified through the workshops with the technical experts from both the pre-assembly and offshore. Especially new dependencies arising from from constraints of locations, resources, equipment and components, were found during these workshops.

Figure 3 illustrates inconsistency in dependencies of the original schedule, multiple starts and stops, some locations having more activities than others without consideration to physical or geographical constraints of the location. Furthermore resource and crane capabilities or productivity rates were not considered aspects in the original schedule. Figure 3 illustrates the workflow of 24 turbines, at pre-assembly which have clear differences in leadtimes. Besides this the original segregation of the project phases is kept, geographically for the pre-assembly areas and offshore turbine by turbine. 


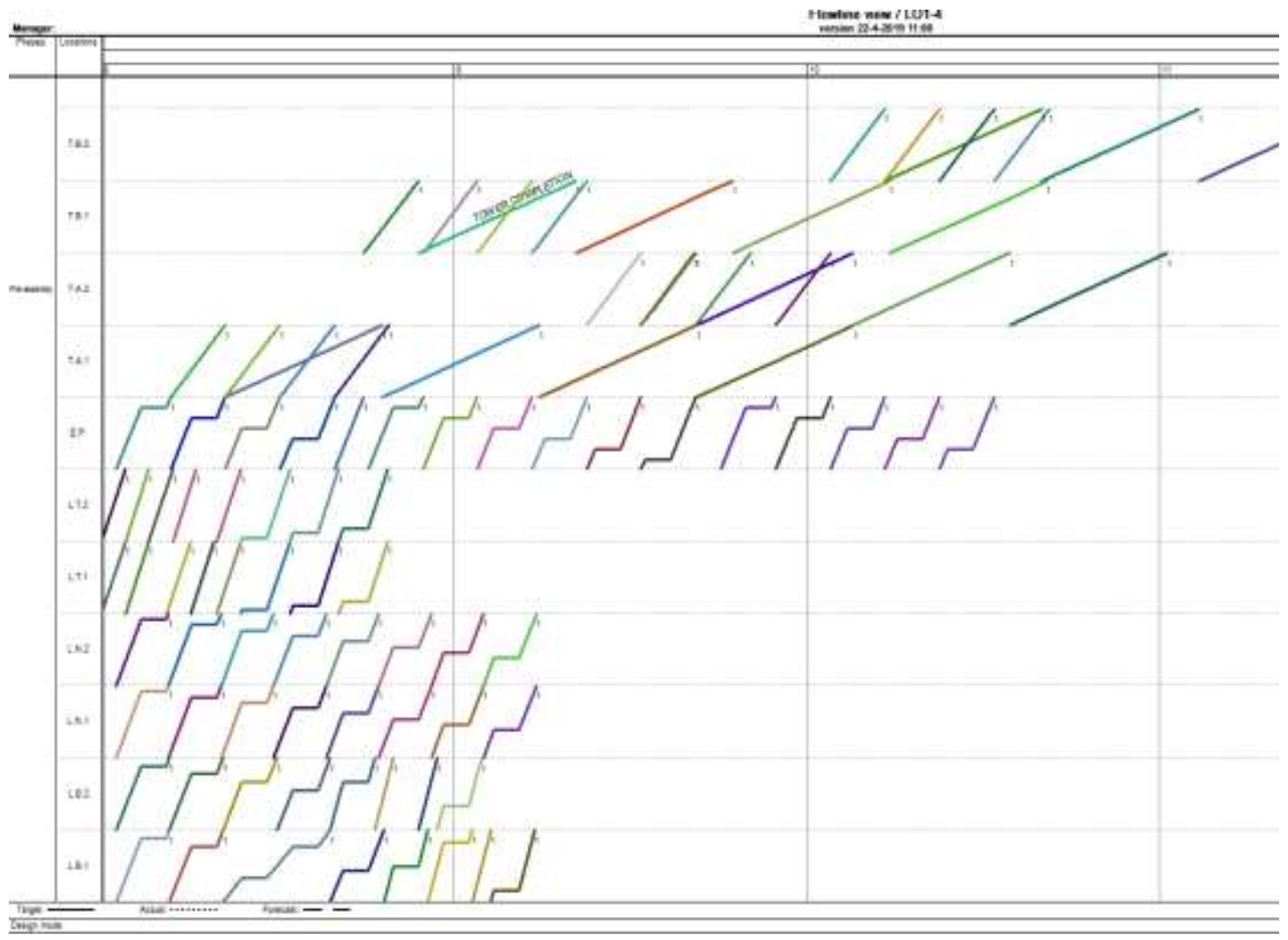

Figure 3: Direct conversion using location segregation from original schedule (Vico Schedule Planner)

\section{DISCUSSION}

The offshore wind literature reviewed indicated a clear preference for using CPM when planning (Alla et al. 2013; Barlow et al. 2015; Irawan et al. 2017) and simulating construction and operations (Backe and Haugland 2017; Barlow et al. 2014; Barlow et al. 2017; Devoy McAuliffe et al. 2018; Hofmann 2011). None of these methods consider resource levelling and workflow as Olivieri et al. (2018), or productivity like Lucko et al. (2014). Seppänen and Aalto (2005) argued for the importance of production rates and early detection of devations which could not be captured by CPM due to buffering. Goldratt (1997) critized CPM for its usage of activity buffers, only Vis and Ursavas (2016) touches upon actively protection of the activites through buffering. Our focus was not on the activity buffering, but it could be argued that it was handled as these buffers were removed through basing the conversion on resource hours per task not the scheduled durations. The offshore weather consists of waves and wind values which are aspects contionsly represented in the literature and not seen similarly in the construction literature. Offshore planning literature argues for inclusion of weather in their planning (Alla et al. 2013; 
Barlow et al. 2014; Barlow et al. 2015; Irawan et al. 2017; Vis and Ursavas 2016) but weather receives few mentions in LBMS literature because several case studies have mostly focused on improving the flow of interior work.

The schedule presented was created with a loop as the LBS was segregated in onshore and offshore, this enabled existing schedules CPM links. For instance fifth layer of CPM links (Kenley and Seppänen 2010) surfaces when relationships between loadout and installation is modeled, as there is a quantity limited buffer at pre-assembly. It could be argued that both offshore and onshore work could have been handled with the same location breakdown because even all offshore work is related to a specific turbine. Understanding the implication of changing the LBS would require further research. Visually, the alternative LBS would show all flowlines flowing through the same locations and the segregation between onshore and offshore could be handled by task naming and coloring.

\section{IMPLICATIONS}

The conversion was not conducted to evaluate the superiority of either planning method in the offshore wind construction context, but solely to test the applicability of LBMS in offshore wind construction. The learnings from the conversion could contribute to the debate of safety in offshore wind (Atkinson 2010) as the task collisions and location availability were made visible during the scheduling. By increasing the visibility of potential delays and thereby making these tangible (Lucko et al. 2014), productivity would then be expected to increase as argued by Seppänen et al. (2014) for construction. The dependencies described here are to the authors knowledge not earlier described, neither for construction industry or project management (Kenley and Seppänen 2010; Lucko et al. 2014), nor by Kenley (2005) within construction refurbishment. Further research might have similar implications as takt planning have had within manufacturing industries (Womack and Jones 2003). This could potentially inspire others to introduce LBMS in other similar industries and thereby strengthen the theory of LBMS.

\section{CONCLUSION}

The assembly of the wind turbine components with its similarities to modules from construction, supports why LBMS is applicable in the context of offshore wind turbine construction. The research also demonstrated that the logical layers for offshore wind turbine construction can be defined and presented in a flowline diagram. The location breakdown structure utilized here could have been changed as discussed. Further research is required to generate further knowledge of how to apply LBMS in practice, and what would be the practical implications of implementing LBMS.

\section{REFERENCE LIST}

Alla, A. A., Quandt, M., and Lütjen, M. (2013). "Simulation-based aggregate installation planning of offshore wind farms." International Journal of Energy, 72, 23-30. 
Atkinson, P. (2010). "Securing the safety of offshore wind workers." Renewable Energy Focus, 11(3), 34-36.

Backe, S., and Haugland, D. "Strategic Optimization of Offshore Wind Farm Installation." Proc., Computational Logistics, Springer International Publishing, 285-299.

Ballard, H. G. (2000). "The last planner system of production control." University of Birmingham.

Barlow, E., Ozturk, D. T., Day, A. H., Boulougouris, E., Revie, M., and Akartunal1, K. (2014). A support tool for assessing the risks of heavy lift vessel logistics in the installation of offshore wind farms.

Barlow, E., Tezcaner Ozturk, D., Day, S., Boulougouris, E., Revie, M., and Akartunali, K. "An assessment of vessel characteristics for the installation of offshore wind farms." Proc., International Conference on Marine Technology ICMT 2014.

Barlow, E., Tezcaner Ozturk, D., Revie, M., Akartunali, K., Day, A., and Boulougouris, E. (2017). "On using simulation to model the installation process logistics for an offshore wind farm."

Barlow, E., Tezcaner Öztürk, D., Revie, M., Boulougouris, E., Day, A. H., and Akartunal1, K. (2015). "Exploring the impact of innovative developments to the installation process for an offshore wind farm." Ocean Engineering, 109(Supplement C), 623-634.

Chris, V., Nikos, T., and Mark, F. (2002). "Case research in operations management." International Journal of Operations \& Production Management, 22(2), 195-219.

Devoy McAuliffe, F., Lynch, K., Sperstad, I. B., Nonås, L. M., Halvorsen-Weare, E. E., Jones, D., Akbari, N., Wall, G., Irawan, C., Norstad, I., Stålhane, M., and Murphy, J. (2018). "The LEANWIND suite of logistics optimisation and full lifecycle simulation models for offshore wind farms." Journal of Physics: Conference Series, 1104, 012002.

Galloway, P. D. (2006). "CPM Scheduling - How Industry Views Its Use." Cost Engineering, 48(1), 24.

Goldratt, E. M. (1997). Critical chain, The North River, Great Barrington, MA.

Hofmann, M. (2011). "A review of decision support models for offshore wind farms with an emphasis on operation and maintenance strategies." Wind Engineering, 35(1), $1-15$.

Irawan, C. A., Jones, D., and Ouelhadj, D. (2017). "Bi-objective optimisation model for installation scheduling in offshore wind farms." Computers and Operations Research, 78, 393-407.

Irawan, C. A., Song, X., Jones, D., and Akbari, N. (2017). "Layout optimisation for an installation port of an offshore wind farm." European Journal of Operational Research, 259(1), 67-83.

Kenley, R. "Dispelling the Complexity Myth: Founding Lean Construction on LocationBased Planning." Proc., 13th Annual Conference of the International Group for Lean ConstructionSydney, Australia, 245-251.

Kenley, R., and Seppänen, O. (2010). Location-based management for construction : planning, scheduling and control, Spon Press, Oxon, OX. 
Kerzner, H., and Kerzner, H. R. (2017). Project management: a systems approach to planning, scheduling, and controlling, John Wiley \& Sons.

Koskela, L. (2000). "An exploration towards a production theory and its application to construction." VTT Publications, X-296.

Lacal-Arántegui, R., Yusta, J. M., and Domínguez-Navarro, J. A. (2018). "Offshore wind installation: Analysing the evidence behind improvements in installation time."

Renewable and Sustainable Energy Reviews, 92, 133-145.

Lucko, G., Alves, T. D. C. L., and Angelim, V. L. (2014). "Challenges and opportunities for productivity improvement studies in linear, repetitive, and location-based scheduling." Construction Management \& Economics, 32(6), 575-594.

Lucko, G., and Gattei, G. (2016). "Line-of-balance against linear scheduling: critical comparison." Proceedings of the Institution of Civil Engineers-Management, Procurement and Law, 169(1), 26-44.

Olivieri, H., Seppänen, O., and Denis Granja, A. (2018). "Improving workflow and resource usage in construction schedules through location-based management system (LBMS)." Construction Management and Economics, 36(2), 109-124.

Paterson, J., D’Amico, F., Thies, P. R., Kurt, R. E., and Harrison, G. (2018). "Offshore wind installation vessels - A comparative assessment for UK offshore rounds 1 and 2." Ocean Engineering, 148, 637-649.

Petersen, K. R., Madsen, E. S., and Bilberg, A. (2016). "First Lean, then modularization: improving the maintenance of offshore wind turbines." International Journal of Energy Sector Management, 10(2), 221-244.

Rodrigues, S., Restrepo, C., Kontos, E., Teixeira Pinto, R., and Bauer, P. (2015). "Trends of offshore wind projects." Renewable and Sustainable Energy Reviews, 49, 1114-1135.

Seppänen, O., Evinger, J., and Mouflard, C. (2014). "Effects of the location-based management system on production rates and productivity." Construction Management and Economics, 32(6), 608-624.

Seppänen, O., and Aalto, E. "A Case Study of Line-of-Balance Based Schedule Planning and Control System." Proc., 13th Annual Conference of the International Group for Lean ConstructionSydney, Australia, 271-279.

Ursavas, E. (2017). "A benders decomposition approach for solving the offshore wind farm installation planning at the North Sea." European Journal of Operational Research, 258(2), 703-714.

Valente, C. P., Montenegro, G. A., Brito, F. L., Biotto, C. N., and Mota, B. P. "Guidelines for Developing a Line of Balance for Non-Repetitive Areas (Common Areas) at a Vertical Residental Building." Proc., 22nd Annual Conference of the International Group for Lean ConstructionOslo, Norway, 763 774.

Vis, I. F. A., and Ursavas, E. (2016). "Assessment approaches to logistics for offshore wind energy installation." Sustainable Energy Technologies and Assessments, 14(Supplement C), 80-91. 
Lerche J, Seppanen. O, Pedersen. KB, Neve. H, Wandahl. S, Gross, A

Vollmann, T., Berry, W., Whybark, D. C., and Jacobs, F. R. (2004). Manufacturing planning and control systems for supply chain management: the definitive guide for professionals, McGraw-Hill Professional.

Womack, J. P., and Jones, D. T. (2003). Lean thinking : banish waste and create wealth in your corporation, Touchstone Books, New York.

Yin, R. K. (1994). Case study research : design and methods, Sage, Thousand Oaks, Calif.

Yin, R. K. (2014). Case study research : design and methods, SAGE, Los Angeles. 